\title{
CADMIUM AND LEAD IN GREY WOLF LIVER SAMPLES: OPTIMISATION OF A MICROWAVE- ASSISTED DIGESTION METHOD
}

\author{
Maja VIHNANEK LAZARUS ${ }^{1}$, Ankica SEKOVANIĆ ${ }^{1}$, Zorana KLJAKOVIĆ-GAŠPIĆ ${ }^{1}$, Tatjana \\ ORCT $^{1}$, Jasna JURASOVIĆ 1 , Josip KUSAK ${ }^{2}$, Slaven RELJIĆ ${ }^{2}$, and Đuro HUBER ${ }^{2}$ \\ Institute for Medical Research and Occupational Health ${ }^{1}$, Zagreb University Faculty of Veterinary Medicine ${ }^{2}$, \\ Zagreb, Croatia
}

Received in November 2012

CrossChecked in November 2012

Accepted in May 2013

\begin{abstract}
A microwave-assisted digestion method for the determination of cadmium $(\mathrm{Cd})$ and lead $(\mathrm{Pb})$ by inductively coupled plasma mass spectrometry (ICP-MS) was optimised on certified reference material (CRM) (bovine liver, BCR-185R) and wolf liver samples. Different factors influencing digestion efficiency (temperature, time, composition of the digestion mixture, sample mass) were tested. Validation included linearity (up to $200 \mu \mathrm{g} \mathrm{L}^{-1}$ for $\mathrm{Cd}$ and $\left.\mathrm{Pb}\right)$, detection $(0.003 \mu \mathrm{g} \mathrm{L}-1$ for $\mathrm{Cd}$ and $0.035 \mu \mathrm{g} \mathrm{L}-1$ for $\mathrm{Pb})$, and quantification $\left(0.008 \mu \mathrm{g} \mathrm{L}^{-1}\right.$ for $\mathrm{Cd}$ and $0.081 \mu \mathrm{g} \mathrm{L}-1$ for $\left.\mathrm{Pb}\right)$ limits. Good agreement between measured and certified values was achieved in all conditions, with recoveries ranging from $94 \%$ to $111 \%$ for $\mathrm{Cd}$ and from $95 \%$ to $105 \%$ for $\mathrm{Pb}$. The precision of the method, expressed as relative standard deviation, was up to $3 \%$ for $\mathrm{Cd}$ and $8 \%$ for $\mathrm{Pb}$. The best digestion parameters $\left(260{ }^{\circ} \mathrm{C}, 30 \mathrm{~min}, 1 \mathrm{mLHNO}_{3}+4 \mathrm{~mL} \mathrm{H}_{2} \mathrm{O}, 0.1 \mathrm{~g}\right.$ of CRM $)$ based on accuracy and precision were applied on two wolf liver samples to evaluate the need for the predigestion step (freeze-drying) and appropriate mass of the sample. Freeze-drying improved precision and minimising the tissue mass to $0.1 \mathrm{~g}$ reduced the matrix effect. Using these optimised digestion conditions, we determined $\mathrm{Cd}$ and $\mathrm{Pb}$ in 40 wolf livers collected in Croatia, and their medians $\left(0.055 \mu \mathrm{g} \mathrm{g}^{-1}\right.$ and $0.107 \mu \mathrm{g} \mathrm{g}^{-1}$, respectively) were in the range of previously reported data for the grey wolf.
\end{abstract}

KEY WORDS: inductively coupled plasma mass spectrometry, reference material bovine liver, toxic metal

Animals positioned on the top of the food web, such as large carnivores, are excellent for monitoring environmental heavy metal contamination (1-4). Among the most common contaminants (As, $\mathrm{Cd}, \mathrm{Cr}$, $\mathrm{Cu}, \mathrm{Hg}, \mathrm{Pb}, \mathrm{V}, \mathrm{Zn}$ ), cadmium (Cd) and lead (Pb) stand out, as they bioaccumulate, have a long biological half-time, and cannot be degraded. As the primary uptake route of $\mathrm{Cd}$ and $\mathrm{Pb}$ is diet $(5,6)$, large carnivores could be at risk of chronic toxicity.

Grey wolf (Canis lupus L., 1758) is one of the three large carnivores (the other two being the lynx and brown bear) inhabiting $32 \%$ of the Croatian territory
(7). This species has been protected by Croatian law since 1995 (8). According to the Wolf Management Plan for Croatia (7), carcasses of accidentally or purposely killed wolves are collected by the Zagreb University Faculty of Veterinary Medicine, and collaboration with the Faculty's experts has given us unique opportunity to study element levels in a relatively large number of wolves. Although wolves in Croatia are a part of a larger Dinaric-Balkan population stretching from Slovenia to Greece and Bulgaria (9), reporting on element status has so far been limited to a study of four animals from Croatia 
(10). In addition, there is only one report from the whole Eurasian continent (north-western Russia), where almost all liver data for $\mathrm{Cd}$ and $\mathrm{Pb}$ were under the limit of detection (11).

The foundation of every quality monitoring are reliable results obtained from sufficiently sensitive analytical methods. Tissue digestion has long been recognised as a critical step in assuring as reproducible and accurate element quantification as possible, without loss of elements (12).

Our study was motivated by the blatant scarcity of element data for the wolf population, but the primary aim was to identify microwave-assisted digestion parameters that would ensure optimal quantification of $\mathrm{Cd}$ and $\mathrm{Pb}$ in animal tissues with inductively coupled plasma mass spectrometry (ICP-MS).

\section{MATERIALS AND METHODS}

\section{Instrumentation}

An UltraCLAVE IV microwave digestion system (Milestone S.r.l., Sorisole, Italy) with integrated software and the cryoLAB cooling system, equipped with 40 Quartz vessels (12-mL capacity) and Teflon caps was used for sample decomposition. A Hetosicc lyophilisator (Heto, Birkerød, Denmark) was used for freeze-drying of wolf liver samples.

Liver $\mathrm{Cd}$ and $\mathrm{Pb}$ were determined using an Agilent 7500cx ICP-MS (Agilent Technologies, Waldbronn, Germany) equipped with an integrated autosampler, a Peltier cooled (at $2{ }^{\circ} \mathrm{C}$ ) Scott-type quartz spray chamber, a MicroMist nebuliser, a collision cell, and Ni cones. Details about the operating conditions and measuring parameters are summarised in Table 1.

We measured ${ }^{114} \mathrm{Cd}$ the most abundant $\mathrm{Cd}$ isotope. Although, known for its isobaric overlap with ${ }^{114} \mathrm{Sn}$ isotope, preliminary measurements showed that $\mathrm{Sn}$ was not quantifiable in liver samples. Germanium and rhodium isotopes ${ }^{72} \mathrm{Ge}$ and ${ }^{103} \mathrm{Rh}$ were used as internal standards to correct for instrumental drift and matrix effects. Initially we added either ${ }^{45} \mathrm{Sc},{ }^{72} \mathrm{Ge},{ }^{74} \mathrm{Ge},{ }^{103} \mathrm{Rh}$, or ${ }^{193} \mathrm{Ir}$ as internal standards that closely match the ionisation energy or atomic mass of $\mathrm{Cd}$ and $\mathrm{Pb}$ to correct for signal instabilities. The concentration of the internal standards in the samples introduced to ICP-MS was $5 \mu \mathrm{g} \mathrm{L}{ }^{-1}$. The best accuracy and precision of measurement in reference material BCR-185R ("no gas mode") was obtained with ${ }^{72} \mathrm{Ge}$ as internal standard for ${ }^{114} \mathrm{Cd}$ and ${ }^{103} \mathrm{Rh}$ for ${ }^{208} \mathrm{~Pb}$.
Our laboratory facilities, designed for routine measurement of trace elements, operate under positive pressure maintained by the HVAC (heating, ventilating, and air conditioning) system combined with HEPA filters.

\section{Reagents and standards}

Ultrapure water $(18 \mathrm{M} \Omega \mathrm{cm})$ obtained with a GenPure system (TKA, Germany) was used for dilution of all solutions and samples. All standard solutions were prepared from a $1000 \mathrm{mg} \mathrm{L}^{-1}$ stock ICP multi-element standard solution IV (Merck, Darmstadt, Germany). Analytical grade nitric acid (65\%, Merck, Darmstadt, Germany) was used after purification by sub-boiling distillation in an ultrapure quartz apparatus (subPUR, Milestone, Italy). Hydrogen peroxide (30\%, Kemika, Zagreb, Croatia) was of analytical grade. All quartz vessels and polypropylene containers were cleaned with detergent solution, soaked in $10 \%$ $\mathrm{HNO}_{3}$ for $24 \mathrm{~h}$, and rinsed with ultrapure water two times.

\section{Samples}

The efficiency of different digestion procedures was evaluated, and the optimised method validated using certified reference material of bovine liver BCR$185 \mathrm{R}$ from the Institute for Reference Materials and Measurements, Geel, Belgium.

The optimised method was then used to prepare different mass aliquots of two wolf liver tissues, both fresh and freeze-dried. Liver was chosen over other tissues due to sufficient supply and satisfactory preliminary measurements (which included muscle, liver, and kidney cortex, data not shown). Frozen wolf liver samples, separately packed in BD Falcon ${ }^{\mathrm{TM}}$ tubes (Becton, Dickinson and Company, New Jersey, NJ, USA) after carcass inspection, were supplied by the Biology Department of the Zagreb University Faculty of Veterinary Medicine. The samples were collected from the Croatian regions of Gorski kotar, Lika, and Dalmatia between November 2008 and October 2010. Prior to analysis, the samples were slightly thawed and rinsed with deionised water. Secondary contamination was avoided by removing the surface liver tissue $(0.5 \mathrm{~cm}$ thick) using stainless steel scissors. Two wolf liver samples, supplied in sufficient amount, were freeze-dried to simulate the texture of certified reference material (BCR-185R), also prepared by freeze-drying, but from bovine liver. 


\section{Multivariate optimisation of the digestion method}

Optimisation was conducted with BCR-185R by changing the following factors that can influence the efficiency of digestion on an UltraCLAVE IV: (1) maximum digestion temperature: $230^{\circ} \mathrm{C}, 245^{\circ} \mathrm{C}$, or $260{ }^{\circ} \mathrm{C} ;(2)$ digestion time at maximum digestion temperature: $15 \mathrm{~min}, 30 \mathrm{~min}$, or $40 \mathrm{~min}$; (3) concentration of the nitric acid: $(4.4,8.8$, or 13.2$) \mathrm{mol} \mathrm{L}^{-1}$ (i.e. $1+4,2+3,3+2$ dilution of the conc. $\mathrm{HNO}_{3}$ with $\mathrm{H}_{2} \mathrm{O}$ ); (4) hydrogen peroxide additions [final concentrations: $(3.9,7.8$, or 11.7$\left.) \mathrm{mol} \mathrm{L}^{-1}\right]$ to nitric acid and water (i.e. $0.6+1+3.4,1.2+2+1.8,1.8+3+0.2$ ); (5) sample mass: $0.1 \mathrm{~g}, 0.2 \mathrm{~g}$, or $0.3 \mathrm{~g}$. Hydrogen peroxide was added to the samples gradually to avoid excess foaming and heating due to abundant release of molecular oxygen and carbon dioxide in exothermic reaction with plenty of organic matter present in samples.

Due to the high cost of CRM we could not afford the full factorial design, but only a few combinations to optimise digestion. The influence of every digestion parameter on $\mathrm{Cd}$ and $\mathrm{Pb}$ recovery from CRM was tested while other variables remained unchanged. The significance of parameter (e.g. temperature) influence on digestion efficiency was established using the oneway analysis of variance (ANOVA). Student's $t$-test was used to determine differences between parameter subgroups (e.g. between $230{ }^{\circ} \mathrm{C}$ and $260{ }^{\circ} \mathrm{C}$ ).

Samples were digested using a modified program UC-10 for the digestion of fresh meat from the UltraCLAVE Application Note (13). The operating program included five steps. While all samples underwent the same $1^{\text {st }}\left(3.5 \mathrm{~min}, 700 \mathrm{~W}, 70{ }^{\circ} \mathrm{C}, 100\right.$ bar), $2^{\text {nd }}\left(15 \mathrm{~min}, 1000 \mathrm{~W}, 180^{\circ} \mathrm{C}, 100 \mathrm{bar}\right)$, and $5^{\text {th }}$ step $\left(40 \mathrm{~min}, 0 \mathrm{~W}, 30^{\circ} \mathrm{C}, 20 \mathrm{bar}\right)$, temperature in the $3^{\text {rd }}$ ramp step (10 min, $1000 \mathrm{~W}, 140 \mathrm{bar}$ ), and temperature and time in the $4^{\text {th }}$ step $(1000 \mathrm{~W}, 140$ bar $)$

Table 1 ICP-MS Agilent 7500cx operating conditions and measurement parameters

\begin{tabular}{lc}
\hline RF Power & $1550 \mathrm{~W}$ \\
\hline Makeup gas flow & $0.2 \mathrm{~L} \mathrm{~min}^{-1}$ \\
\hline Carrier gas flow & $0.94 \mathrm{~L} \mathrm{~min}^{-1}$ \\
\hline Sample Depth & $8.3 \mathrm{~mm}$ \\
\hline Torch-H & $0.4 \mathrm{~mm}$ \\
\hline Torch-V & $0.2 \mathrm{~mm}$ \\
\hline Nebulizer pump & $0.08 \mathrm{rps}$ \\
\hline Extract lens 1 voltage & $0.5 \mathrm{~V}$ \\
\hline Extract lens 2 voltage & $-126 \mathrm{~V}$ \\
\hline Integration time & $0.5 \mathrm{~s}$ \\
\hline Monitored isotopes & ${ }^{114} \mathrm{Cd} \mathrm{and}{ }^{208} \mathrm{~Pb}$ \\
\hline
\end{tabular}

were alternated to determine optimum conditions. After completion of the temperature program and release of the pressure inside the reaction chamber, quartz vessels were allowed to cool to room temperature. The content of the digestion vessels was quantitatively transferred to polypropylene tubes and diluted to $6 \mathrm{~mL}$ with ultrapure water. Two method blank samples were run with each batch of samples during the optimisation to identify possible contamination during digestion and analysis.

Optimal digestion conditions [Step 3: ramp (180 to 260$)^{\circ} \mathrm{C}$ in $10 \mathrm{~min}$; Step 4: hold at $260{ }^{\circ} \mathrm{C}$ for $30 \mathrm{~min}$ ] were then applied for the digestion of the wolf liver samples, while optimising sample mass to meet the criteria of reproducibility, but with as low total dissolved solids (TDS) in digested solution as possible. About $0.1 \mathrm{~g}, 0.2 \mathrm{~g}$ or $0.3 \mathrm{~g}$ of freeze-dried and $0.3 \mathrm{~g}$, $0.6 \mathrm{~g}$ or $0.9 \mathrm{~g}$ of fresh wolf liver in four replicates each were digested with $4.4 \mathrm{~mol} \mathrm{~L}^{-1}$ nitric acid.

All samples for $\mathrm{Cd}$ and $\mathrm{Pb}$ analysis were additionally diluted by factor of 10 with ultrapure water before analysis. Three replicate measurements were made for each sample. Blank concentration values were subtracted from measured sample concentrations.

\section{RESULTS AND DISCUSSION}

\section{Analytical performance}

Typical equations for calibration curves for $\mathrm{Cd}$ and $\mathrm{Pb}$ were $\mathrm{Y}=20212 \mathrm{X}+44 ; \mathrm{R}^{2}=1$ and $\mathrm{Y}=33932 \mathrm{X}+175$; $\mathrm{R}^{2}=1$, respectively. They were constructed using external standards and stretched well within the wide linear dynamic range of ICP-MS (up to $200 \mu \mathrm{g} \mathrm{L}^{-1}$ ). Limits of detection (LOD), calculated as average concentration of the blanks plus three times the standard deviation of the blanks $(n=12)$ were $0.003 \mu \mathrm{g} \mathrm{L}{ }^{-1}$ for $\mathrm{Cd}$ and $0.035 \mu \mathrm{g} \mathrm{L^{-1 }}$ for $\mathrm{Pb}$. Limits of quantification (LOQ) calculated for each element as average concentration of the blanks plus ten times the standard deviation were $0.008 \mu \mathrm{g} \mathrm{L}^{-1}$ for $\mathrm{Cd}$ and $0.081 \mu \mathrm{g} \mathrm{L}^{-1}$ for $\mathrm{Pb}$. The relatively higher LOD and LOQ for $\mathrm{Pb}$ could be the result of secondary contamination during sample preparation without a clean bench.

The accuracy of the digestion method, expressed as recovery, was assessed by comparing results obtained under variable conditions of digestion with certified values for BCR-185R. Good agreement between measured and certified values was achieved in all conditions, with recoveries ranging from $94 \%$ 
to $111 \%$ for $\mathrm{Cd}$ and from $95 \%$ to $105 \%$ for $\mathrm{Pb}$ (Table 2). Measured and certified values were compared using Student's $t$-test. Statistically significant differences, where found, are indicated by superscripts in uppercase next to accuracy (Table 2).

The precision of the method, expressed as relative standard deviation (RSD), was up to $3 \%$ for $\mathrm{Cd}$ and $8 \%$ for $\mathrm{Pb}$ (Table 2 ).

\section{Optimisation of microwave-assisted digestion}

Colourless digestion solutions without visible precipitate and high recovery results for $\mathrm{Cd}$ and $\mathrm{Pb}$ in BCR-185R (Table 2) indicated that samples from all experiments were completely digested. The only exceptions were digestion solutions with the highest mass of CRM and fresh/freeze-dried wolf liver, which were light yellow. According to Kingston et al. (14) and Wasilewska et al. (15), yellow colour indicates the presence of a large amount of organic substances in the digest. However, even a clear solution can give no reliable information about the amount of remaining organic compounds.

All our parameter combinations showed satisfactory recoveries and precision (Table 2) and even though some results significantly differed from the reference value, they all fell within the certified range for both $\mathrm{Cd}$ and $\mathrm{Pb}$.

\section{Temperature}

The temperature of decomposition influences how complete the degradation of organic matter will be. In our study, digestion efficiency did not differ significantly between temperature subgroups (Table 2). Good recoveries and precision for $\mathrm{Cd}$ and $\mathrm{Pb}$ were obtained at all studied temperatures. Our optimal temperature was $260^{\circ} \mathrm{C}$, as higher temperatures improve the oxidising ability of nitric acid (14). Higher temperature applied in the fourth step of our digestion increased the pressure $\left(\Delta \mathrm{t}=30^{\circ} \mathrm{C} ; \Delta \mathrm{p}=25\right.$ bar $)$. This pressure build-up in the digestion vessel during the final phase of decomposition was probably caused by $\mathrm{CO}_{2}$ development from carbon contained in the sample, generation of $\mathrm{NO} / \mathrm{NO}_{2}$ in reaction with nitric acid, and the vapour pressure of water and nitric acid $(15,16)$.

\section{Time}

After the first three steps of microwave digestion, in which temperature reached $260^{\circ} \mathrm{C}$ in less than $30 \mathrm{~min}$, we measured the hold time at this temperature.
We set a relatively long ramp time to prevent the occurrence of pressure and temperature spikes resulting from very exothermic and pressure-intensive reactions. Good accuracy and precision were observed at all three proposed times of digestion. Although our results have shown that even $15 \mathrm{~min}$ at $260^{\circ} \mathrm{C}$ were enough to effectively decompose our samples, we opted for $30 \mathrm{~min}$ as optimum time to ensure as low total organic carbon (TOC) as possible. According to Wasilewska et al. (15), time of optimised digestion reduced by $30 \%$ significantly increases the TOC value.

\section{Composition of digestion mixture}

\section{Nitric acid}

Nitric acid is the most common digestion reagent for organic matrices, used to decompose samples before quantitative trace element measurements. In our third experiment (Table 2), we used different ratios of concentrated nitric acid and water $(1+4,2+3$, and $3+2)$ to prepare different concentrations of nitric acid $\left[(4.4,8.8\right.$, or 13.2$\left.) \mathrm{mol} \mathrm{L}^{-1}\right]$ in digestion solution. The addition of water to the reaction mixture helps to solubilise ions and molecules released from the matrix when reaction solution gets saturated and prevents temperature and pressure spiking in rapid closedvessel decompositions (14). Other benefits of diluted nitric acid versus concentrated acid as digestion reagent are discussed by Castro et al. (17). Increasing nitric acid solution concentration in our study resulted in lower recovery for $\mathrm{Cd}$, even though the difference was significant only between the group with the lowest nitric acid concentration and the ones obtained with $8.8 \mathrm{~mol} \mathrm{~L}^{-1}(p<0.001)$ or $13.2 \mathrm{~mol} \mathrm{~L}^{-1}(p<0.01)$. The decrease in $\mathrm{Pb}$ recovery was not significant. In conclusion, the lowest acid concentration solution used for digestion $\left(4.4 \mathrm{~mol} \mathrm{~L}^{-1}\right)$ showed the best recovery for both elements. In addition, low solution acidity prolongs the life of the sample and skimmer cones and prevents problems with pneumatic nebulisation and aerosol formation (17).

\section{Nitric acid and hydrogen peroxide}

Hydrogen peroxide is often used in combination with nitric acid for the digestion of biological matrices because of its good oxidising potential that increases with acidity, leading to improved metal extraction efficiency compared to extraction with nitric acid alone. In addition, hydrogen peroxide (35 \%) improves 
Table 2 Accuracy (as percent recovery) and precision (as relative standard deviation) determined for cadmium and lead in CRM bovine liver under varying digestion parameters.

\begin{tabular}{|c|c|c|c|c|c|c|c|c|c|c|c|}
\hline \multirow{2}{*}{$\begin{array}{l}\text { Ex- } \\
\text { peri- } \\
\text { ment }\end{array}$} & \multirow{2}{*}{$\begin{array}{l}\text { Tempe- } \\
\text { rature / } \\
{ }^{\circ} \mathrm{C}\end{array}$} & \multirow[t]{2}{*}{$\begin{array}{l}\text { Time } \\
\text { / min }\end{array}$} & \multirow[t]{2}{*}{$\begin{array}{l}\mathrm{HNO}_{3} / \\
\mathrm{mol} \mathrm{L}^{-1}\end{array}$} & \multirow[t]{2}{*}{$\begin{array}{l}\mathrm{H}_{2} \mathrm{O}_{2} / \\
\mathrm{mol} \mathrm{L}^{-1}\end{array}$} & \multirow[t]{2}{*}{$\begin{array}{l}\text { Sample } \\
\text { mass / g }\end{array}$} & \multicolumn{3}{|c|}{$\begin{array}{c}C d \\
\text { R.V. }=0.544 \pm 0.017 \mu g^{-1}\end{array}$} & \multicolumn{3}{|c|}{ 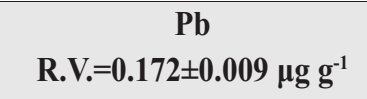 } \\
\hline & & & & & & $\begin{array}{c}\text { Recovery }^{*} \\
/ \%\end{array}$ & $\begin{array}{c}\text { RSD / } \\
\%\end{array}$ & $p^{\#}$ & $\begin{array}{c}\text { Recovery }^{*} \\
/ \%\end{array}$ & $\begin{array}{c}\text { RSD / } \\
\%\end{array}$ & $p^{\#}$ \\
\hline \multirow[t]{3}{*}{1} & 230 & 30 & 4.4 & - & 0.3 & 102 & 2.1 & & 103 & 5.1 & \\
\hline & 245 & 30 & 4.4 & - & 0.3 & 100 & 1.3 & & $97^{\mathrm{a}}$ & 1.2 & \\
\hline & 260 & 30 & 4.4 & - & 0.3 & 100 & 0.5 & & 101 & 5.1 & \\
\hline \multirow[t]{3}{*}{2} & 260 & 15 & 4.4 & - & 0.3 & 99 & 0.6 & $\mathrm{~B}^{\mathrm{a}} \mathrm{C}^{\mathrm{a}}$ & $98^{\mathrm{a}}$ & 1.5 & \\
\hline & 260 & 30 & 4.4 & - & 0.3 & 100 & 0.5 & $\mathrm{~A}^{\mathrm{a}}$ & 101 & 5.1 & \\
\hline & 260 & 40 & 4.4 & - & 0.3 & 101 & 1.1 & $\mathrm{~A}^{\mathrm{a}}$ & 101 & 8.3 & \\
\hline \multirow[t]{3}{*}{3} & 260 & 30 & 4.4 & - & 0.3 & 100 & 0.5 & $\mathrm{~B}^{\mathrm{c}} \mathrm{C}^{\mathrm{b}}$ & 101 & 5.1 & \\
\hline & 260 & 30 & 8.8 & - & 0.3 & $96^{\mathrm{b}}$ & 0.7 & $\mathrm{~A}^{\mathrm{c}}$ & $96^{\mathrm{b}}$ & 1.2 & \\
\hline & 260 & 30 & 13.2 & - & 0.3 & $94^{a}$ & 2.4 & $\mathrm{~A}^{\mathrm{b}}$ & 97 & 5.5 & \\
\hline \multirow[t]{3}{*}{4} & 260 & 30 & 4.4 & 3.9 & 0.3 & $111^{\mathrm{c}}$ & 0.4 & $\mathrm{~B}^{\mathrm{c}} \mathrm{C}^{\mathrm{c}}$ & $105^{\mathrm{a}}$ & 2.6 & $\mathrm{~B}^{\mathrm{c}} \mathrm{C}^{\mathrm{b}}$ \\
\hline & 260 & 30 & 8.8 & 7.8 & 0.3 & 100 & 1.7 & $\mathrm{~A}^{\mathrm{c}}$ & $95^{\mathrm{b}}$ & 1.7 & $\mathrm{~A}^{\mathrm{c}}$ \\
\hline & 260 & 30 & 13.2 & 11.7 & 0.3 & 99 & 2.2 & $\mathrm{~A}^{\mathrm{c}}$ & 98 & 1.8 & $\mathrm{~A}^{\mathrm{b}}$ \\
\hline \multirow[t]{3}{*}{5} & 260 & 30 & 4.4 & - & 0.1 & 102 & 2.6 & & 104 & 2.6 & \\
\hline & 260 & 30 & 4.4 & - & 0.2 & 101 & 2.4 & & 101 & 0.7 & \\
\hline & 260 & 30 & 4.4 & - & 0.3 & 100 & 0.5 & & 101 & 5.1 & \\
\hline
\end{tabular}

${ }^{*}$ Lowercase superscript indicates significant result of t-test between mean $(\mathrm{N}=4)$ and certified reference value $(R . V):.{ }^{a} \mathrm{p}<0.05$, ${ }^{b} \mathrm{p}<0.01,{ }^{c} \mathrm{p}<0.001$.

"Uppercase indicates significant result of t-test between measured means $(\mathrm{N}=4)$ of two subgroups; A: Significantly different from the first (of three) subgroup of matching digestion parameter (i.e. temperature, time, acid concentration...), B: Significantly different from the second subgroup of matching digestion parameter, C: Significantly different from the third subgroup of matching digestion parameter. Lowercase superscript indicates significance level of t-test: ${ }^{a} \mathrm{p}<0.05,{ }^{b} \mathrm{p}<0.01,{ }^{c} \mathrm{p}<0.001$.

the conversion of microwave energy into heat because of its high dielectric constant (14). In our study, the influence of nitric acid:hydrogen peroxide mixture concentrations on $\mathrm{Cd}$ and $\mathrm{Pb}$ recoveries (Table 2) was notable only between the first subgroup with the lowest nitric acid:hydrogen peroxide mixture concentrations (4.4 mol L-1 $\mathrm{HNO}_{3}: 3.9 \mathrm{~mol} \mathrm{~L}^{-1} \mathrm{H}_{2} \mathrm{O}_{2}$ ) and the other two mixtures $(p<0.01)$. The lowest acid-hydrogen peroxide mixture yielded worse recoveries for $\mathrm{Cd}$ $(p<0.001)$ than the matching acid solutions $\left(4.4 \mathrm{~mol} \mathrm{~L}^{-1}\right.$ $\mathrm{HNO}_{3}$ ). As for $\mathrm{Pb}$, it made no significant difference whether we used acid alone or an acid/peroxide mixture. Veschetti et al. (18) reported that different digestion mixtures applied on sewage-sludge had no effect on metal content, but that hydrogen peroxide added to nitric acid reduced the dissolved organic carbon content by $14 \%$. Although in our study hydrogen peroxide combined with the lowest concentrations of nitric acid yielded higher recoveries for $\mathrm{Cd}$ but lower accuracies, nitric acid alone was strong enough to completely digest the samples. One of the drawbacks when using hydrogen peroxide in closed-vessel decomposition system is a relatively small quantity of hydrogen peroxide that can be added because of the large quantities of molecular oxygen produced. This limits its efficiency compared to traditional open-vessel systems where large aliquots of fresh reagent are frequently added (14). Furthermore, gradual addition of hydrogen peroxide - to reduce foaming - prolonged the pre-digestion time of our samples for up to an hour (at $1.8 \mathrm{~mL}$ hydrogen peroxide) and consequently the whole sample preparation. An alternative would have been to use larger sample vessels that would contain the foam. Finally, hydrogen peroxide of analytical grade used in our experiments contained a high amount of $\mathrm{Cd}$ and $\mathrm{Pb}$ impurities (manufacturer declared it contained $\leq 1 \mu \mathrm{g} \mathrm{g}^{-1}$ heavy metals), which affected LOD. This is why we recommend the use of suprapure hydrogen peroxide. The above reasons tipped the scales against acid-hydrogen peroxide mixture and in favour of acid solution alone.

\section{Sample mass}

Two very important factors for complete oxidation of organic substances are the amount of organic 
sample and striking the optimal ratio between sample mass and acid volume or vessel volume $(16,19)$. In our fifth experiment (Table 2), sample size had no influence on digestion efficiency and $\mathrm{Cd}$ and $\mathrm{Pb}$ recoveries. Even the lowest amount of BCR-185R sample $(0.1 \mathrm{~g})$, recommended by the producer as minimum analytical portion, yielded acceptable results. Similarly, Hassan et al. (19) reported significantly improved recoveries when sample mass to acid volume ratio was reduced 10 times. Wasilewska et al. (15) have shown that doubling the bovine liver sample mass from $0.2 \mathrm{~g}$ to $0.4 \mathrm{~g}$ resulted in twice as high TOC at temperatures from $220{ }^{\circ} \mathrm{C}$ to $250{ }^{\circ} \mathrm{C}$. This is why we opted for the lowest, $0.1 \mathrm{~g}$ mass as optimal.

\section{Wolf liver analysis}

We applied the optimised digestion parameters to further study the effects of sample mass and an additional pre-digestion step (freeze-drying) on two wolf liver samples. Digestion with or without the freeze-drying step (Table 3 ) produced significantly different $\mathrm{Cd}$ and $\mathrm{Pb}$ levels only in liver $2(p<0.05)$, which, regardless of sample mass, had higher element levels when fresh tissue was analysed. This inconsistency between the two wolf livers would have been overcome if more liver samples had been involved in the study, and we plan to carry out a more comprehensive research with more liver samples.

However, relative standard deviations $(0.3 \%$ to $4.3 \%$ for freeze-dried livers, $1.4 \%$ to $13 \%$ for fresh livers) suggest that freeze-drying helps to improve precision. This is expected, since freeze-drying is widely used for minimising physical and chemical changes in samples during storage (20). However, in our study, freeze-drying prolonged sample preparation for $24 \mathrm{~h}$.

In some liver samples, mass had a significant influence (ANOVA, Student's $t$-test) on element levels, whether the pre-digestion step was taken or not (Table 3 ), but element levels did not follow the increase in sample mass. A decision about tissue mass for digestion should take into account the following criteria: element content should be above the quantification limit; matrix effect should be as low as possible; and sample tissue should be available in sufficient quantities.

Table 3 Cadmium and lead levels in freeze-dried and fresh grey wolf liver samples as a function of mass fraction $\left(\mu g g^{-1}\right)$.

\begin{tabular}{|c|c|c|c|c|c|}
\hline \multirow[t]{2}{*}{ Wolf sample } & \multirow[t]{2}{*}{ Sample mass / g } & \multicolumn{2}{|c|}{$\mathrm{Cd} / \mu \mathrm{g} \mathrm{g}^{-1}$} & \multicolumn{2}{|c|}{$\mathrm{Pb} / \mu \mathrm{g} \mathrm{g}^{-1}$} \\
\hline & & mean $\pm \mathrm{SD}^{*}$ & RSD / \% & mean $\pm \mathrm{SD}^{*}$ & RSD / \% \\
\hline \multirow{3}{*}{ freeze-dried liver 1} & 0.1 & $0.106 \pm 0.002$ & 2.2 & $1.348 \pm 0.029^{\mathrm{Ca}}$ & 2.1 \\
\hline & 0.2 & $0.101 \pm 0.004^{\mathrm{Ca}}$ & 4.3 & $1.323 \pm 0.005^{\mathrm{Ca}}$ & 0.3 \\
\hline & 0.3 & $0.108 \pm 0.001^{\mathrm{Ba}}$ & 1.1 & $1.290 \pm 0.019^{\mathrm{AaBa}}$ & 1.4 \\
\hline \multirow{3}{*}{ freeze-dried liver 2} & 0.1 & $0.214 \pm 0.003$ & 1.4 & $0.062 \pm 0.000^{\mathrm{Cb}}$ & 0.5 \\
\hline & 0.2 & $0.213 \pm 0.009$ & 4.0 & $0.062 \pm 0.002$ & 3.2 \\
\hline & 0.3 & $0.218 \pm 0.004$ & 1.6 & $0.060 \pm 0.001^{\mathrm{Ab}}$ & 1.4 \\
\hline \multirow{3}{*}{ fresh liver 1} & 0.3 & $0.092 \pm 0.005$ & 5.4 & $1.321 \pm 0.042$ & 3.2 \\
\hline & 0.6 & $0.111 \pm 0.014$ & 13.0 & $1.411 \pm 0.133$ & 9.4 \\
\hline & 0.9 & $0.099 \pm 0.009$ & 9.0 & $1.220 \pm 1.127$ & 10.4 \\
\hline \multirow{3}{*}{ fresh liver 2} & 0.3 & $0.233 \pm 0.005^{\mathrm{BaCa}}$ & 2.3 & $0.066 \pm 0.002$ & 3.5 \\
\hline & 0.6 & $0.219 \pm 0.007^{\mathrm{Aa}}$ & 3.0 & $0.064 \pm 0.001$ & 1.4 \\
\hline & 0.9 & $0.218 \pm 0.007^{\mathrm{Aa}}$ & 3.4 & $0.063 \pm 0.003$ & 4.4 \\
\hline
\end{tabular}

*Uppercase superscript indicates significant result of t-test between means $(\mathrm{N}=4)$ of two subgroups of the same wolf liver; ${ }^{A}$ Significantly different from the first (of three) subgroup of sample mass, ${ }^{B}$ Significantly different from the second subgroup of sample mass. 'Significantly different from the third subgroup of sample mass. Lowercase superscript indicates significance level of t-test: ${ }^{a} \mathrm{p}<0.05,{ }^{b} \mathrm{p}<0.01$

Table 4 Cadmium and lead levels $\left(\mu \mathrm{g} \mathrm{g}^{-1}\right)$ in the liver of 40 grey wolfs from Croatia

\begin{tabular}{lcc}
\hline Wolf liver & $\mathbf{C d} / \boldsymbol{\mu} \mathbf{g ~ \mathbf { g } ^ { - 1 }}$ & $\mathbf{P b} / \boldsymbol{\mu} \mathbf{g ~ g}^{-\mathbf{1}}$ \\
\hline $\mathrm{N}$ & 40 & 40 \\
\hline Mean $\pm \mathrm{SD}$ & $0.084 \pm 0.088$ & $0.194 \pm 0.263$ \\
\hline Median & 0.055 & 0.107 \\
\hline Range & 0.0092 to 0.414 & 0.037 to 1.30 \\
\hline
\end{tabular}


Once we had optimised all digestion parameters, we tested the method on 40 grey wolf liver samples. Table 4 shows somewhat higher $\mathrm{Pb}$ than $\mathrm{Cd}$ levels, but in a narrower range. Our findings matched well with an earlier report for four animals from Croatia (10) and with the results for the arctic wolf(subspecies of grey wolf) from Yukon (1). Data about wolves from north-western Russia (11) are very scarce because of high method LODs, which were three and four orders of magnitude higher than ours for $\mathrm{Pb}$ and $\mathrm{Cd}$, respectively. The only three detectable levels of $\mathrm{Pb}$ in the study of Shore et al. (11) were all higher than our highest $\mathrm{Pb}$ measurements.

\section{CONCLUSION}

Microwave-assisted digestion is a powerful method for the preparation of tissue samples for environmental monitoring, both fresh and freezedried. It ensures total recovery of low-level $\mathrm{Cd}$ and $\mathrm{Pb}$ from the matrix and subsequent quantification with ICP-MS. Our optimised operating mode $\left(260{ }^{\circ} \mathrm{C}\right.$ for 30 min with $4.4 \mathrm{~mol} \mathrm{~L}^{-1}$ nitric acid added to $0.1 \mathrm{~g}$ of CRM bovine liver or freeze-dried wolf liver) ensured as accurate and precise quantification of $\mathrm{Cd}$ and $\mathrm{Pb}$ as possible. Freeze-drying, although time consuming, has shown to improve precision. A comprehensive multi-element study of various wolf tissues is planned in the future to explore possible age and sex differences and element interactions within wolf tissues.

\section{Acknowledgments}

This study was supported by the Ministry of Science, Education and Sports of the Republic of Croatia (Grant no. 022-0222148-2135). The statistical advice of Ms Jelena Kovačić and language advice of Mr Dado Čakalo are gratefully acknowledged. We also wish to thank the members of the Croatian Wolf Emergency Team for their help in collecting the wolf tissue samples.

\section{REFERENCES}

1. Gamberg M, Braune BM. Contaminant residue levels in arctic wolves (Canis lupus) from the Yukon Territory, Canada. Sci Total Environ 1999;243/244:329-38. doi: 10.1016/S00489697(99)00408-8

2. Rush SA, Borgå K, Dietz R, Born EW, Sonne C, Evans T, Muir DC, Letcher RJ, Norstrom RJ, Fisk AT. Geographic distribution of selected elements in the livers of polar bears from Greenland, Canada and the United States. Environ Pollut 2008;153:618-26. doi: 10.1016/j. envpol.2007.09.006

3. Hoffmann SR, Blunck SA, Petersen KN, Jones EM, Koval JC, Misek R, Frick JA, Cluff HD, Sime CA, McNay M, Beckman KB, Atkinson MW, Drew M, Collinge MD, Bangs EE, Harper RG. Cadmium, copper, iron, and zinc concentrations in kidneys of grey wolves, Canis lupus, from Alaska, Idaho, Montana (USA) and the Northwest Territories (Canada). Bull Environ Contam Toxicol 2010;85:481-5. doi: 10.1007/s00128-010-0126-6

4. Sonne C. Health effects from long-range transported contaminants in Arctic top predators: An integrated review based on studies of polar bears and relevant model species. Environ Int 2010;36:461-91. doi: 10.1016/j. envint.2010.03.002

5. Nordberg GF, Fowler BA, Nordberg M, Friberg L. Introduction-general considerations and international perspectives. In: Nordberg GF, Fowler BA, Nordberg M, Friberg L, editors. Handbook on the toxicology of metals. $3^{\text {rd }}$ ed. San Diego, London: Academic Press; 2007. p. 1-9.

6. Merian E, Anke M, Ihnat M, Stoeppler M, editors. Elements and Their Compounds in the Environment. Weinheim: Wiley$\mathrm{VCH} ; 2004$

7. Štrbenac A, Huber Đ, Kusak J, Jeremić J, Oković P, MajićSkrbinšek A, Vukšić I, Katušić L, Desnica S, Gomerčić T, Bišćan A, Zec D, Grubešić M. Plan upravljanja vukom u Republici Hrvatskoj za razdoblje 2010.-2015. [The Plan for Wolf Management in Croatia 2010-2015, in Croatian]. Zagreb: Državni zavod za zaštitu prirode; 2010.

8. Pravilnik o zaštiti pojedinih vrsta sisavaca (Mammalia) [Regulation on the protection of certain species of mammals (Mammalia), in Croatian]. Narodne novine 31/1995.

9. Kaczensky P, Chapron G, Arx M, Huber Đ, Andrén H, Linnell J, editors. Status, management and distribution of large carnivores - bear, lynx, wolf \& wolverine - in Europe [displayed 4 June 2013]. Available at http://www. carnivorescience.org/files/2013 EUCommission carnivorestatus-2.pdf

10. Bilandžić N, Dežđek D, Sedak M, Dokić M, Šimić B, Rudan N, Brstilo M, Lisicin T. Trace elements in tissues of wild carnivores and omnivores in Croatia. Bull Environ Contam Toxicol 2012;88:94-9. doi: 10.1007/s00128-011-0449-y

11. Shore RF, Casulli A, Bologov V, Wienburg CL, Afsar A, Toyne P, Dell'Omo G. Organochlorine pesticide, polychlorinated biphenyl and heavy metal concentrations in wolves (Canis lupus L. 1758) from north-west Russia. Sci Total Environ 2001;280:45-54. doi: 10.1016/S00489697(01)00802-6

12. Lamble KJ, Hill SJ. Microwave digestion procedures for environmental matrices. Analyst 1998;123:103R-33R. doi: 10.1039/A800776D

13. UltraCLAVE Application Note N. UC-10. In: UltraCLAVE IV user manual Rev. 02/2008. Leutkirch: MLS-Milestone GmbH Mikrowellen-Laborsysteme.

14. Kingston HM, Walter PJ, Chalk S, Lorentzen E, Link D. Environmental microwave sample preparation: Fundamentals, methods, and applications. In: Kingston HM, Haswell SJ, editors. Microwave-enhanced chemistry. Fundamentals, sample preparation, and applications. Washington: American Chemical Society; 1997. p. 223-340. 
15. Wasilewska M, Goessler W, Zischka M, Maichin B, Knapp G. Efficiency of oxidation in wet digestion procedures and influence from the residual carbon content on selected techniques for determination of trace elements. J Anal At Spectrom 2002;17:1121-5. doi: 10.1039/B200644H

16. Knapp G, Panholzer F, Schalk A, Kettisch P. Pressurecontrolled microwave-assisted wet digestion systems. In: Kingston HM, Haswell SJ, editors. Microwave-enhanced chemistry. Fundamentals, sample preparation, and applications. Washington: American Chemical Society; 1997. p. 423-43.

17. Castro JT, Santos EC, Santos WPC, Costa LM, Korn M, Nóbrega JA, Korn MGA. A critical evaluation of digestion procedures for coffee samples using diluted nitric acid in closed vessels for inductively coupled plasma optical emission spectrometry. Talanta 2009;78:1378-82. doi: 10.1016/j.talanta.2009.02.030

18. Veschetti E, Maresca D, Cutilli D, Santarsiero A, Ottaviani M. Optimization of $\mathrm{H}_{2} \mathrm{O}_{2}$ action in sewage-sludge microwave digestion using $\Delta$ pressure vs. temperature and pressure vs. time graphs. Microchem J 2000;67:171-9. doi: 10.1016/ S0026-265X(00)00114-4

19. Hassan NM, Rasmussen PE, Dabek-Zlotorzynska ED, Celo $\mathrm{V}$, Chen H. Analysis of environmental samples using microwave assisted acid digestion and inductively coupled plasma mass spectrometry: maximizing total element recoveries. Water Air Soil Pollut 2007;178:323-34. doi: 10.1007/s11270-006-9201-3

20. Arruda MAZ, editor. Trends in Sample Preparation. New York: Nova Science Publishers; 2007. 


\section{Sažetak}

\section{KADMIJ I OLOVO U UZORCIMA VUČJE JETRE: OPTIMIZACIJA METODE RAZGRADNJE UZORAKA UZ POMOĆ MIKROVALOVA}

Certificirani referenti materijal (CRM) govedskih jetara (BCR-185R) i uzorci vučjih jetara koristili su se za optimizaciju metode razgradnje uzoraka prije mjerenja kadmija $(\mathrm{Cd})$ i olova $(\mathrm{Pb})$ masenom spektrometrijom induktivno spregnute plazme (ICP-MS). Ispitivani su različiti uvjeti koji utječu na učinkovitost razgradnje (temperatura, vrijeme, sastav otopine za razgradnju, masa uzorka). Validacijom je obuhvaćeno ispitivanje linearnosti (do $200 \mu \mathrm{g} \mathrm{L}^{-1} \mathrm{Cd} / \mathrm{Pb}$ ), granice detekcije $\left(0,003 \mu \mathrm{g} \mathrm{L} \mathrm{L}^{-1} \mathrm{za} \mathrm{Cd}, 0.035\right.$ $\left.\mu \mathrm{g} \mathrm{L}^{-1} \mathrm{za} \mathrm{Pb}\right)$ i kvantifikacije $\left(0,008 \mu \mathrm{g} \mathrm{\textrm {L } ^ { - 1 }} \mathrm{za} \mathrm{Cd}, 0,081 \mu \mathrm{g} \mathrm{L} \mathrm{L}^{-1} \mathrm{za} \mathrm{Pb}\right)$. Postignuto je dobro slaganje izmjerenih i certificiranih vrijednosti u svim ispitivanim uvjetima uz izračunati raspon iskorištenja $94 \%$ do $111 \%$ za Cd i $95 \%$ do $105 \%$ za Pb. Najveća relativna standardna devijacija, kao mjera preciznosti, iznosila je 3 $\%$ za Cd i $8 \%$ za Pb. Najbolji uvjeti za razgradnju $\left(260{ }^{\circ} \mathrm{C}, 30 \mathrm{~min}, 1 \mathrm{~mL} \mathrm{HNO}_{3}+4 \mathrm{~mL} \mathrm{H} 2 \mathrm{O}, 0,2 \mathrm{~g} \mathrm{CRM}\right)$, izabrani prema točnosti i preciznosti, primijenjeni su na uzorke vučjih jetara pri procjeni odgovarajuće mase uzorka i potrebe za uvođenjem dodatnog koraka prije razgradnje (liofilizacije). Liofilizacija poboljšava preciznost pa je preporučujemo pri pripremi uzoraka tkiva. Također, najmanja masa uzorka izabrana je ne samo zbog bolje preciznosti nego i zbog najmanjeg utjecaja matrice te potrebne količine tkiva. Medijani $\mathrm{Cd}\left(0,055 \mu \mathrm{g} \mathrm{g}^{-1}\right)$ i $\mathrm{Pb}\left(0,107 \mu \mathrm{g} \mathrm{g} \mathrm{g}^{-1}\right.$ mokre mase) dobiveni analizom 40 uzoraka vučjih jetara skupljenih u Hrvatskoj bili su u rasponu vrijednosti objavljenih u literaturi za sivog vuka.

KLJUČNE RIJEČI: masena spektrometrija induktivno spregnute plazme, otrovni metal, referentni materijal, govedska jetra, vučja jetra

\section{CORRESPONDING AUTHOR:}

Maja Vihnanek Lazarus

Institute for Medical Research and Occupational Health

Ksaverska cesta 2, P.O. Box 291, HR-10001 Zagreb, Croatia

E-mail:mlazarus@imi.hr 